\title{
PENAMBAHAN GETAH PEPAYA (Carica papaya) PADA PAKAN PELET DENGAN DOSIS YANG BERBEDA UNTUK PERTUMBUHAN DAN KELANGSUNGAN HIDUP IKAN MAS (Cyprinus carpio)
}

\section{THE ADDITION OF DIFFERENT DOSES OF PAPAYA SAP (Carica papaya) ON PELLET FEED FOR CARP (Cyprinus carpio) GROWTH AND SURVIVAL RATE}

\author{
Sri Yulianti $1^{*}$, Nurliah $^{1)}$, Dewi Putri Lestari ${ }^{1)}$, \\ ${ }^{1)}$ Program Studi Budidaya Perairan, Universitas Mataram \\ Jl. Pendidikan No. 37 Mataram, Nusa Tenggara Barat
}

\begin{abstract}
Abstrak
Tujuan penelitian ini adalah untuk mengetahui pengaruh penambahan getah pepaya pada pakan pelet terhadap pertumbuhan berat mutlak, efisiensi pakan, kecernaan total dan kelangsungan hidup ikan mas. Penelitian ini menggunakan rancangan acak lengkap (RAL) dengan perlakuan : pakan tanpa penambahan getah $(\mathrm{P} 0)$, penambahan getah $1 \%(\mathrm{P} 1)$, penambahan getah $2 \%(\mathrm{P} 2)$, penambahan getah $2,5 \%$ (P3), penambahan getah 3\% (P4) dari bobot pakan yang diberikan. Data yang diperoleh dianalisis menggunakan ANOVA dengan taraf nyata 5\%. Hasil penelitian menunjukkan bahwa penambahan getah pepaya pada pakan yang digunakan dalam penelitian ini tidak memberikan pengaruh signifikan terhadap pertumbuhan berat mutlak, efisiensi pakan, kecernaan total, dan kelangsungan hidup ikan mas. Akan tetapi, pertumbuhan berat mutlak, efisiensi pakan dan kecernaan total ikan mas yang diberi pakan dengan penambahan getah pepaya $1 \%$ memberikannilai yang cenderung lebih tinggi dibandingkan dengan perlakuan yang lain.
\end{abstract}

Kata kunci : pertumbuhan, efisiensi pakan, kecernaan total, getah pepaya, ikan mas.

\begin{abstract}
The aims of this research is to know the effect of the addition of the papaya sap feed on growth, feed efficiency, digestibility and the survival rate of a carp. This study used a randomized complete design (RAL) with 4 treatments:without the addition of sap (P0), the addition of sap $1 \%(\mathrm{P} 1)$, the addition of sap 2\% (P2), the addition of sap 2.5\% (P3), the addition of sap 3\% (P4) from the given feed weights. The data were analyzed using ANOVA with the significance level of 5\%. The results showed that the addition of the sap feed on papaya was not provide significant effects on the growth, digestibility, feed efficiency, viability of carp. However, absolute weight growth, feed efficiency, and total digestibility of carp fed with $1 \%$ addition of papaya sap gave a value that tended to be higher compared to other treatments.
\end{abstract}

Keywords : growth, feed efficiency, total digestibility, sap of papaya, carp.

\section{Pendahuluan}

Ikan mas (Cyprinus carpio) adalah salah satu ikan air tawar yang diminati oleh masyarakat. Perkembangan usaha pembesaran ikan mas sangat pesat, sehubungan dengan permintaan ikan konsumsi oleh masyarakat. Hingga tahun 2002, ikan mas mendominasi produksi akuakultur air tawar di Indonesia. Berdasarkan data statistik tahun 2012 produksi ikan mas mencapai 374.366 dan tahun 2013

*email korespondensi :

Sri.yulianti31@yahoo.com mencapai 412.736 ton. Angka ini terus meningkat seiring bangkitnya sentra-sentra budidaya ikan mas (Direktorat Jenderal Perikanan Budidaya Kementerian Kelautan dan Perikanan, 2014).

Ikan mas disukai oleh masyarakat karena selain rasanya enak juga mengandung nutrisi yang baik. Ikan mas mengandung protein 4,5 gr, karbohidrat 23,1 gr, lemak 0,2 gr, fosfor 134 $\mathrm{mg}$, kalsium $42 \mathrm{mg}$, besi $1 \mathrm{mg}$ dan vitamin B1 0,22 gr dan air $71 \mathrm{mg}$ (Yulianto, 2013). Selain 
itu, ikan mas diminati oleh pembudidaya karena mempunyai pertumbuhan yang cepat dan dapat dibudidayakan secara intensif dengan padat penebaran tinggi sebanyak $80-100$ ekor $/ \mathrm{m}^{2}$. Akan tetapi, padat penebaran yang tinggi menyebabkan pembudidaya memerlukan pakan ikan yang lebih banyak untuk menunjang pertumbuhan ikan. Hal ini disebabkan karena protein dari pakan kurang diserap oleh ikan (Ananda dkk., 2015)

Salah satu solusi yang dapat dilakukan untuk mempercepat penyerapan protein dari pakan adalah dengan penambahan enzim pada pakan (Anugraha dkk., 2014). Peran enzim sangat penting dalam proses pencernaan protein dimana protein berfungsi sebagai kompenen struktural penyusun sel dan jaringan tubuh baru untuk pertumbuhan. Penggunaan enzim untuk meningkatkan pertumbuhan ikan sudah pernah dilakukan sebelumnya (Khodijah dkk., 2015). Hasil penelitian tersebut yang menggunakan enzim papain komersil, menunjukkan bahwa laju pertumbuhan relativ, rasio efisiensi protein, efisiensi pemanfaatan pakan lebih baik dibanding pakan tanpa penambahan enzim.

Enzim mempunyai kemampuan katalitik yang sangat besar sehingga enzim mampu mempercepat reaksi dibanding reaksi-reaksi tanpa enzim (DeMan, 1997). Enzim juga memiliki spesifitas terhadap substrat dari reaksi yang dikatalisnya. Proses pencernaan melibatkan komponen bahan yang dicerna (makanan), saluran atau tempat dan kelenjar pencernaan (hati dan pankreas). Pencernaan protein menjadi asam amino dikatalis oleh enzim protease (DeMan, 1997). Salah satu enzim protease adalah papain.

Papain merupakan enzim proteolitik yang terkandung dalam getah pepaya (Carica papaya) (Arum dkk., 2014) dan saat ini sudah tersedia dalam bentuk komersil. Namun harga enzim papain komersil relative mahal. Maka alternatif yang bisa dilakukan yaitu menggunakan enzim papain yang diambil langsung dari getah pepaya. Akan tetapi, dosis terbaik yang dapat digunakan untuk mempercepat pencernaan protein pada ikan belum diketahui.

Penelitian ini bertujuan untuk mengetahui pengaruh penambahan getah pepaya (Carica papaya) pada pakan buatan terhadap pertumbuhan berat mutlak, efisiensi pakan, kecernaan total, dan kelangsungan hidup ikan mas (Cyprinus carpio).

\section{Metode Penelitian}

Penelitian ini dilaksanakan mulai bulan Juni-Agustus 2018. Pembuatan papain kasar dilakukan pada tanggal 27 Juni 2018. Pemeliharaan ikan dilaksanakan selama 40 hari pada tanggal 29 Juni - 7 Agustus 2018 di Laboratorium Perikanan Program Studi Budidaya Perairan Universitas Mataram. Pengujian energi dilaksanakan selama 2 hari pada 14 Agustus -15 Agustus 2018 di Laboratorium Nutrisi dan Makan an Ternak Fakultas Peternakan Universitas Udayana Bali.

Rancangan penelitian ini menggunakan Rancangan Acak Lengkap (RAL). Penelitian ini terdiri dari 5 perlakuan dan 3 kali ulangan, sehingga digunakan 15 unit percobaan. Perlakuan dosis getah adalah P0 (Pakan tanpa penambahan getah), P1 (Pakan yang ditambahkan getah dengan dosis 1\%), P2 (Pakan yang ditambahkan getah 1,5\%), P3 (Pakan yang ditambahkan getah 2\%), dan P4 (Pakan yang ditambahkan getah 3\%) dari bobot pakan buatan yang diberikan.

\section{Persiapan Enzim Papain Kasar}

Pepaya kuning disadap dari bagian buah sebanyak $200 \mathrm{ml}$. Kemudian getah dicampur dengan larutan pengaktif. Larutan pengaktif dibuat dengan mencampurkan 1 liter aquades dengan $3 \mathrm{ml} \mathrm{NaCl}$ dan $12 \mathrm{~g}$ Natrium bisulfit sebanyak 4 kali jumlah getah. Larutan getah diaduk hingga merata dengan alat pengaduk (mixer) sampai membentuk emulsi getah. Emulsi getah dimasukkan dalam loyang, kemudian dimasukkan dalam oven dengan suhu $65{ }^{\circ} \mathrm{C}$ selama 7 jam hingga berbentuk sepihan-serpihan berwarna putih kekuningan, kemudian sepihan putih digerus hingga berbentuk tepung. Penyimpanan enzim papain kasar dilakukan dalam tabung tertutup rapat dan disimpan pada suhu $25{ }^{\circ} \mathrm{C}$ (Suyanti dkk., 2012). Pada penelitian ini $200 \mathrm{ml}$ getah pepaya menghasilkan $82,80 \mathrm{~g}$ papain kasar.

\section{Analisis Aktivitas Enzim Papain Kasar}

Analisis aktivitas enzim papain dengan MCU mengikuti prosedur kerja dari Sani (2008) yaitu papain kering ditimbang 1 gram kemudian papain diberi air secukupnya sampai larut. Setelah itu, dimasukkan papain kedalam labu ukur $100 \mathrm{ml}$ dan ditambah aquadest sampai $100 \mathrm{ml}$. Dikocok selama 30 menit dan disentrifugasi sampai didapatkan larutan jernih papain. Disiapkan 12 gram susu full cream dan 
dilarutkan ke dalam air sampai $100 \mathrm{ml}$ kemudian dimasukkan ke dalam tabung reaksi dan dimasukkan ke dalam oven dengan suhu 40 ${ }^{0} \mathrm{C}$. Larutan papain jernih diambil $1 \mathrm{ml}$ dengan pipet volume dimasukkan ke dalam larutan susu yang ada dalam oven. Digoyang perlahan larutan tersebut dan suhunya dipertahankan pada $40{ }^{\circ} \mathrm{C}$. Penggumpalan susu terjadi pada waktu 1,10 menit.

\section{Persiapan Penelitian}

Alat-alat dan wadah penelitian dicuci terlebih dahulu agar terbebas dari penyakit. Wadah penelitian menggunakan sistem resirkulasi. Benih didapatkan dari Balai Budidaya Ikan Batu Kumbung. Benih diadaptasi terlebih dahulu. Benih yang digunakan sebanyak 150 ekor. Setelah itu, ikan ditangkap menggunakan seser dan dipindah ke dalam akuarium yang sudah disiapkan sesuai perlakuan dengan padat tebar 10 ekor/52,5 L. Ikan mas akan dipelihara selama 40 hari. Pergantian filter akan dilakukan $1 \mathrm{x}$ seminggu tanpa penggantian air.

Persiapan pakan akan dilakukan dengan cara melarutkan enzim papain kasar dengan akuades secukupnya. Setelah itu. menyemprotkan larutan enzim papain secara merata pada pellet sesuai dengan dosis perlakuan. Pelet diangin-anginkan dalam ruangan, kemudian diberikan pada pakan uji dan sisanya disimpan dalam kulkas suhu $5^{0} \mathrm{C}$ (Usman, 2014). Pemberian pakan dilakukan dengan sampai kenyang (ad satiation). Frekuensi pemberian pakan 2x sehari pada pagi (08.00) dan sore (16.00).

\section{Analisa Data}

Parameter yang diuji yaitu pertumbuhan berat mutlak atau Growth Rate $(\mathrm{GR})=W t-$ $W 0$; efisiensi pakan $(\mathrm{E})=\frac{[(W t+W d)-W 0]}{F} \times 100$; kecernaan total $(\mathrm{D})=\frac{I-f}{I} \times 100 \%$; dan kelangsungan hidup $(\mathrm{SR})=\frac{N t}{N o} \times 100 \%$. GR= pertumbuhan berat mutlak, $\mathrm{Wt}=$ rata-rata bobot ikan pada akhir pemeliharaan $(\mathrm{g}), \mathrm{W} 0=$ ratarata bobot ikan pada awal pemeliharaan $(\mathrm{g}), \mathrm{E}=$ efisiensi pakan (\%), $\mathrm{Wd}=$ bobot ikan yang mati selama pemeliharaan $(\mathrm{g}), \mathrm{F}_{\text {kering }}=$ jumlah pakan yang dikonsumsi selama pemeliharaan $(\mathrm{g}), \mathrm{D}$ $(\%)=$ kecernaan total, $\mathrm{I}=$ total kandungan energi pakan yang dikonsumsi (g), $\mathrm{F}=$ total kandungan energi dalam feses (g), SR $(\%)=$ kelangsungan hidup, $\mathrm{Nt}=$ jumlah ikan pada akhir pemeliharaan (ekor), dan $\mathrm{N} 0=$ jumlah ikan pada awal pemeliharaan (ekor). Parameter kualitas air yang diamati yaitu $\mathrm{pH}$, Oksigen terlarut dan suhu. Pengecekan parameter kualitas air dilakukan setiap 1x seminggu pada pagi hari. Data hasil percobaan dianalisis dengan Analysis of Variance (ANOVA) pada taraf nyata $5 \%$.

\section{Hasil}

Berdasarkan hasil uji Anova penambahan getah pepaya pada pakan tidak memberikan pengaruh yang nyata $(\mathrm{P}>0.05)$ terhadap pertumbuhan berat mutlak, efisiensi pakan, kecernaan total, dan kelangsungan hidup ikan mas. Hasil Pengamatan terhadap pertumbuhan berat mutlak, efisiensi pakan, kecernaan total dan kelangsungan hidup ikan mas dapat dilihat pada Tabel 1.

\section{Pertumbuhan berat mutlak}

Penambahan getah pepaya pada pakan dengan dosis berbeda tidak memberikan pengaruh yang nyata terhadap pertumbuhan berat mutlak ikan mas. Namun, pertumbuhan berat mutlak ikan mas dengan perlakuan penambahan getah pepaya $1 \%$ cenderung lebih tinggi dibandingkan dengan perlakuan yang lain dan cenderung menurun seiring penambahan dosis getah pepaya, sedangkan pada perlakuan tanpa penambahan getah pepaya menunjukkan hasil yang cenderung lebih rendah daripada perlakuan yang lain (Gambar 1).

\section{Efisiensi pakan}

Penambahan getah pepaya pada pakan tidak memberikan pengaruh yang nyata $(\mathrm{P}>0.05)$ terhadap efisiensi pakan ikan mas. Namun demikian, efisiensi pakan ikan mas dengan perlakuan penambahan getah pepaya $1 \%$ cenderung lebih tinggi dibandingkan dengan perlakuan yang lain. Pada perlakuan penambahan getah pepaya $2 \%, 2,5 \%$ dan $3 \%$ menghasilkan nilai efisiensi pakan yang cenderung menurun seiring dengan adanya peningkatan penambahan getah pepaya (Gambar 2). Namun, nilai tersebut cenderung lebih rendah dibandingkan dengan perlakuan kontrol tanpa penambahan getah papaya. 
Tabel 1. Berat mutlak (g), efisiensi pakan (\%), kecernaan total (\%), dan kelangsungan hidup (\%) yang dipelihara selama 40 hari dengan penambahan dosis getah pepaya yang berbeda

\begin{tabular}{llllll}
\hline Parameter & \multicolumn{5}{c}{ Perlakuan } \\
\cline { 2 - 6 } & \multicolumn{1}{c}{ P0 } & \multicolumn{1}{c}{ P1 } & \multicolumn{1}{c}{ P2 } & \multicolumn{1}{c}{ P3 } & \multicolumn{1}{c}{ P4 } \\
\hline BM $(\mathrm{g}))^{\mathrm{ns}}$ & $4.23 \pm 2.032$ & $8.4 \pm 3.324$ & $6.52 \pm 2.041$ & $5.19 \pm 2.351$ & $5.64 \pm 2.658$ \\
EP(\%) $)^{\text {ns }}$ & $40.08 \pm 4.867$ & $52.94 \pm 3.900$ & $39.76 \pm 4.019$ & $34.20 \pm 4.643$ & $33.84 \pm 3.203$ \\
KT (\%) $)^{\text {ns }}$ & 80.77 & 83.19 & 80.63 & 73.32 & 80.37 \\
SR $(\%)^{\text {ns }}$ & $90 \pm 2.513$ & $83.33 \pm 1.920$ & $90 \pm 2.059$ & $83.33 \pm 2.359$ & $83.33 \pm 1.694$ \\
\hline
\end{tabular}

Keterangan: ${ }^{\mathrm{ns}}=$ non signifikan $(\mathrm{P}>0,05)$, angka setelah \pm adalah nilai standart error, berat mutlak $(\mathrm{BM})$, efisiensi pakan (EP), kecernaan total (KT), dan survival rate (SR).

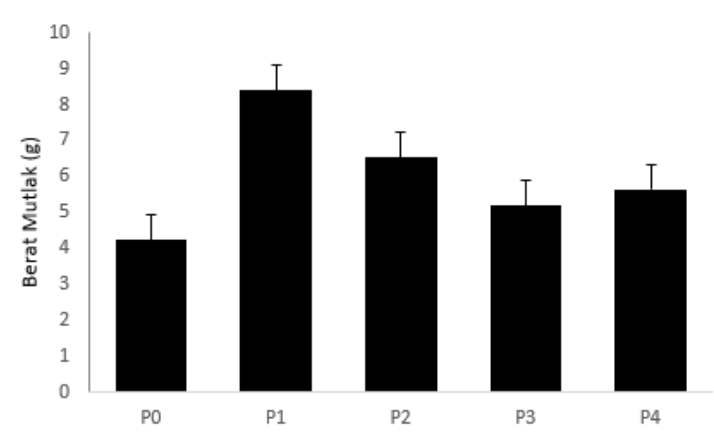

Gambar 1. Pertumbuhan berat mutlak ikan mas yang diberikan pakan dengan penambahan dosis getah yang berbeda. : P0 (Tanpa Penambahan Getah), P1 (Penambahan Getah $1 \%$ ), (Penambahan Getah 2\%), P3 (Penambahan Getah 2,5\%), dan P4 (Penambahan Getah 3\%)

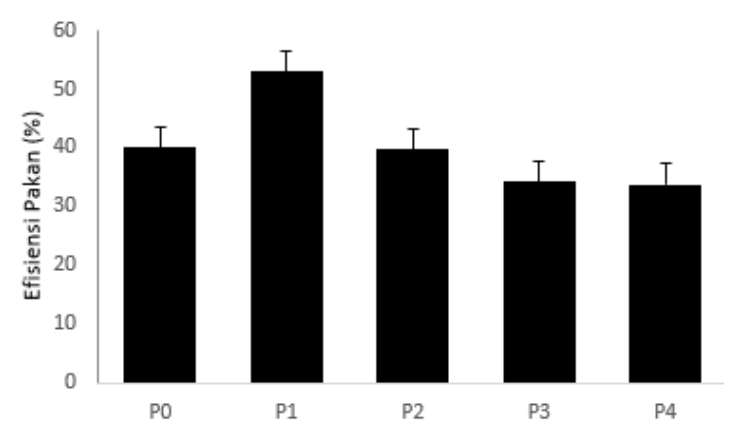

Gambar 2. Efisiensi pakan ikan mas yang diberikan pakan dengan penambahan getah pepaya dengan dosis yang berbeda. P0 (Tanpa Penambahan Getah), P1 (Penambahan Getah 1\%), (Penambahan Getah 2\%), P3 (Penambahan Getah 2,5\%), dan P4 (Penambahan Getah 3\%).

\section{Kecernaan total}

Penambahan getah pepaya pada pakan tidak memberikan pengaruh yang nyata $(\mathrm{P}>0.05)$ terhadap kecernaan total pakan ikan mas. Namun demikian, kecernaan total pakan ikan mas dengan perlakuan penambahan getah pepaya $1 \%$ cenderung lebih tinggi dibandingkan dengan perlakuan yang lain dan penambahan getah pepaya $2,5 \%$ cenderung rendah daripada perlakuan yang lain. Pada perlakuan kontrol tanpa penambahan getah pepaya menghasilkan nilai kecernaan yang cenderung lebih tinggi dibandingkan dengan penambahan getah pepaya $2 \%$ dan $3 \%$ (Gambar 3).

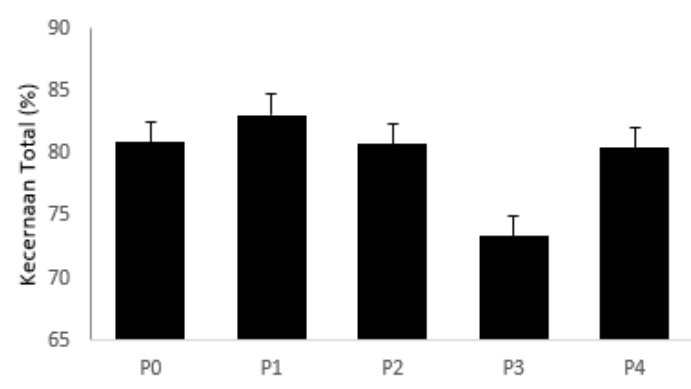

Gambar 3. Kecernaan total pakan ikan mas yang diberikan pakan dengan penambahan getah pepaya dengan dosis yang berbeda. P0 (Tanpa Penambahan Getah), P1 (Penambahan Getah 1\%), (Penambahan Getah 2\%), P3 (Penambahan Getah 2,5\%), dan P4 (Penambahan Getah 3\%). 


\section{Tingkat kelangsungan hidup}

Hasil pengamatan tingkat kelangsungan hidup ikan mas pada perlakuan kontrol tanpa penambahan getah pepaya dan penambahan getah pepaya $2 \%$ menghasilkan tingkat kelagsungan hidup yang cenderung sama dan cenderung lebih tinggi daripada perlakuan yang lain. Sedangkan penambahan getah pepaya $1 \%$, $2,5 \%$ dan $3 \%$ menghasilkan tingkat kelangsungan hidup yang sama namun cenderung lebih rendah daripada perlakuan yang lain (Gambar 4).

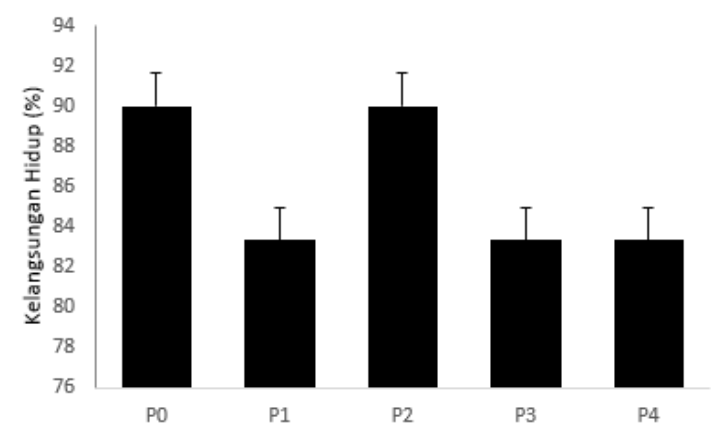

Gambar 4. Tingkat kelangsungan hidup ikan mas yang diberikan pakan dengan penamabahan getah pepaya dengan dosis yang berbeda. P0 (Tanpa Penambahan Getah), P1 (Penambahan Getah 1\%), (Penambahan Getah 2\%), P3 (Penambahan Getah 2,5\%), dan P4 (Penambahan Getah 3\%).

\section{Kualitas air}

Selama penelitian tidak dilakukan penggantian air namun hanya mengganti filter berupa kapas saring 1 minggu sekali dan penyiponan setiap hari pada media pemeliharaan. Media pemeliharaan menggunakan sistem resirkulasi 24 jam. Ratarata kisaran parameter kualitas air selama pemeliharaan dapat dilihat pada Tabel 2 .

\section{Pembahasan}

\section{Pertumbuhan Berat Mutlak Ikan Mas}

Penelitian penambahan getah pepaya dengan dosis yang berbeda pada pakan tidak memberikan pengaruh yang nyata terhadap pertumbuhan berat mutlak ikan mas. Hal ini menunjukkan bahwa penambahan getah pepaya dalam pakan uji belum mampu memberikan peningkatan secara nyata terhadap pertumbuhan berat mutlak ikan mas. Kurang signifikannya pertumbuhan berat mutlak diduga masih rendahnya aktivitas enzim papain dalam getah pepaya yang digunakan dalam penelitian ini yaitu 90,91 MCU/g. Berdasarkan hasil penelitian Ananda dkk. (2015), penambahan enzim papain komersil $0,75 \%$ pada pakan buatan memberikan pertumbuhan spesifik ikan patin tertinggi sebesar $2,37 \%$ /hari. Selanjutnya, hasil penelitian Hutabarat dkk. (2016), penambahan enzim papain $2 \% / \mathrm{kg}$ pakan memberikan pertumbuhan spesifik ikan lele dumbo tertinggi sebesar 2,69\%/hari.

Berat mutlak ikan mas yang dipelihara selama 40 hari yang diberikan pakan dengan penambahan getah pepaya $1 \%$ sebesar $8,4 \mathrm{~g}$ memiliki berat mutlak yang cenderung lebih tinggi dibandingkan dengan tanpa penambahan getah maupun dengan penambahan getah $2 \%$, $2,5 \%$ dan 3\%. Hal ini diduga karena penambahan getah pepaya $1 \% /$ bobot pakan adalah kadar enzim papain yang baik untuk ikan mas sehingga pakan lebih cepat dicerna dan menghasilkan pertumbuhan yang lebih baik. Selain itu, hewan uji diduga belum mampu menyerap kandungan enzim papain pada getah pepaya yang diberikan.

Hasil pengamatan juga menunjukkan bahwa pertumbuhan berat mutlak cenderung menurun dengan adanya peningkatan dosis penambahan getah pepaya. Menurut Oliveira dkk. (2011) bahwa kandungan senyawa aktif yang

Tabel 2. Kualitas air selama pemeliharaan

\begin{tabular}{lllllll}
\hline \multirow{2}{*}{ Parameter } & \multicolumn{7}{c}{ Perlakuan } & \multirow{2}{*}{ Referensi } \\
\cline { 2 - 6 } & \multicolumn{1}{c}{ P0 } & \multicolumn{1}{c}{ P1 } & \multicolumn{1}{c}{ P2 } & \multicolumn{1}{c}{ P3 } & \multicolumn{1}{c}{ P4 } & \\
\hline Suhu $\left({ }^{0} \mathrm{C}\right)$ & $26.7-27.4$ & $26.9-27.4$ & $26.7-27.3$ & $26.7-27.5$ & $26.7-27.4$ & $26-30^{*}$ \\
DO $(\mathrm{mg} / \mathrm{l})$ & $4.8-6.5$ & $4.7-6.5$ & $4.7-6.6$ & $4.4-6.5$ & $4.8-6.6$ & $>3$ \\
pH & $7-7.9$ & $7-7.9$ & $7-7.9$ & $7-7.8$ & $7-7.9$ & $7-8,5^{* * *}$ \\
\hline Ket. $\left.:^{*}\right)$ Arifin dkk. (2007), $\left.{ }^{* *}\right)$ Zonneveld dkk. (1991), ${ }^{* * *}$ )Effendi (2003) dalam Putranti dkk. (2015). &
\end{tabular}

terkandung dalam getah pepaya adalah flavonoid, alkaloid, tannin, triterpenoid, steroid dan saponin. Senyawa golongan alkaloid yang 
bersifat racun adalah homolycorine dan tazettine (Ningrum dkk., 2016). Saponin termasuk racun yang menghancurkan butir darah atau hemolisis pada darah, bersifat racun pada hewan berdarah dingin dan biasa disebut sapotoksin (Rachman dkk., 2015). Menurut Puspaningsih (2003) dalam Rohyami (2008) bahwa flavonoid memberikan efek toksisitas akut pada larva Artemia salina. Senyawa tannin apabila dikonsumsi dalam jumlah berlebihan akan menghambat penyerapan mineral misalnya besi (Ismarani, 2012).

\section{Efisiensi Pakan}

Efisiensi pakan menunjukkan seberapa banyak pakan yang dimanfaatkan untuk pertumbuhan. Berdasarkan hasil penelitian, penambahan getah pepaya dalam pakan belum mampu memberikan peningkatan secara nyata terhadap nilai efisiensi pakan. Namun, efisiensi pakan ikan mas dengan penambahan getah $1 \%$ memiliki nilai efisiensi pakan yang cenderung lebih tinggi daripada perlakuan yang lain. Hal ini menunjukkan bahwa pakan yang dikonsumsi dengan penambahan getah pepaya $1 \%$ mudah dicerna dan dimanfaatkan secara efisien oleh ikan mas. Menurut Craig dan Helfrich (2002) dalam Ananda dkk. (2015), pakan dapat dikatan baik apabila nilai efisiensi pakan lebih dari 50\%. Papain dalam getah pepaya mampu menghidrolisis protein yang terkandung dalam pakan menjadi asam amino sehingga pakan yang diberikan memiliki daya serap dan cerna yang tinggi. Hal ini menyebabkan pakan termanfaatkan secara efisien dan mempengaruhi nilai efisiensi pakan (Ananda dkk., 2015).

Nilai efisiensi pakan yang rendah menunjukkan ikan membutuhkan pakan dalam jumlah yang lebih banyak untuk meningkatkan berat tubuhnya. Hanya sebagian kecil energi pakan yang digunakan untuk pertumbuhan. Sebagian besar energi dari makanan digunakan untuk pemeliharaan, sisanya untuk aktivitas, pertumbuhan dan reproduksi (Haryanto dkk., 2014). Menurut Handajani dan Widodo (2010), faktor yang mempengaruhi makanan terhadap pertumbuhan antara lain aktivitas fisiologi, proses metabolisme dan daya cerna (digestible) yang berbeda pada setiap individu ikan. Jika tingkat energi protein pakan melebihi kebutuhan, maka akan menurunkan konsumsi sehingga pengambilan nutrient lainnya akan menurun. Oleh karena itu, diperlukan keseimbangan yang tepat antara energi dan protein agar dicapai keefisienan dan keefektifan pemanfaatan pakan (Putranti dkk., 2015).

\section{Kecernaan Total}

Kecernaan adalah parameter yang menunjukkan berapa dari pakan yang dikonsumsi dapat diserap oleh tubuh ikan. Nilai kecernaan pakan dapat menggambarkan kemampuan ikan dalam mencerna pakan dan kualitas pakan yang dikonsumsi (Affandi dkk., 1992 dalam Gusrina, 2008). Pada Tabel 1. terlihat penambahan getah pepaya dalam pakan belum mampu memberikan peningkatan yang nyata terhadap kecernaan total pakan ikan mas. Namun, penambahan getah pepaya $1 \%$ memiliki kecernaan total cenderung lebih tinggi mencapai 83,04\% daripada perlakuan yang lain (Gambar 3). Menurut Heper (1988) dalam Gusrina (2008) kecernaan pakan dipengaruhi oleh keberadaan enzim dalam saluran pencernaan ikan, tingkat aktivitas enzim-enzim pencernaan dan lamanya pakan yang dimakan bereaksi dengan enzim pencernaan. Setiap faktor tersebut akan dipengaruhi oleh faktor sekunder yang berhubungan dengan spesies ikan, umur dan ukuran ikan, kondisi lingkungan, serta pakan yang dikonsumsi.

Apabila nilai kecernaan suatu pakan rendah menunjukkan bahwa pakan yang diberikan tidak dapat dimanfaatkan secara optimal oleh ikan. Kecernaan pakan dipengaruhi oleh faktor fisik dan kimia makanan, jenis makanan, kandungan gizi makanan, jumlah enzim pencernaan pada sistem pencernaan ikan, ukuran ikan serta sifat fisik dan kimia perairan (Lestari, 2001 dalam Putranti, 2015).

\section{Tingkat Kelangsungan Hidup Ikan Mas}

Penambahan getah pepaya pada pakan tidak mempengaruhi secara nyata terhadap tingkat kelangsungan hidup ikan mas. Hal ini sesuai dengan hasil penelitian Hasan (2000) bahwa penambahan enzim papain pada pakan tidak memberikan pengaruh yang nyata terhadap kelangsungan hidup benih ikan gurame. Selanjutnya, Rachmawati dkk. (2016) menyatakan bahwa penambahan enzim papain pada pakan tidak memberikan pengaruh yang nyata terhadap kelangsungan hidup ikan lele. Tingkat kelangsungan hidup ikan mas mencapai $90 \%$. Tingginya nilai kelangsungan hidup diduga karena pakan yang diberikan cukup untuk kelangsungan hidup ikan serta media pemeliharaan ikan masih dalam kisaran 
optimal (Tabel 2) untuk kelangsungan hidup ikan mas.

Tingkat kelangsungan hidup ikan terutama dipengaruhi oleh sifat fisika kimia air, media dan kualitas pakan. Ketersediaan makanan dalam penelitian ini sudah cukup untuk memenuhi kebutuhan ikan mas dalam mendukung kelangsungan hidupnya. Kematian benih ikan mas terjadi pada awal penelitian diduga karena ikan masih beradaptasi terhadap pakan dengan perlakuan yang diberikan. Selain itu, kematian ikan diduga karena kandungan amoniak yang tinggi pada media pemeliharaan karena tidak dilakukan penggantian air selama penelitian. Menurut Haryanto dkk. (2014) kadar amoniak $\left(\mathrm{NH}_{3}\right)$ yang tinggi dapat mempengaruhi pertumbuhan ikan dan bersifat toksik terhadap ikan. Menurut Hepher (1988) dalam Rachmawati dkk. (2016) besar kecilnya kelangsungan hidup dipengaruhi oleh faktor internal seperti ketahanan terhadap penyakit, umur, keturunan dan jenis kelamin, serta faktor eksternal seperti jumlah dan komposisi kelengkapan asam amino dalam pakan, padat penebaran dan kualitas air media pemeliharaan.

\section{Kualitas Air}

Pengukuran kualitas air dilakukan seminggu sekali selama penelitian. Kenaikan dan penurunan suhu, $\mathrm{pH}$ dan kandungan oksigen tidak terlalu signifikan karena media pemeliharaan merupakan wadah yang terkontrol. Pada Tabel 2 terlihat suhu pada semua perlakuan berkisar $26-27,5{ }^{\circ} \mathrm{C}$. Nilai ini masih optimal untuk kelangsungan hidup ikan mas. Hal ini sesuai dengan pendapat Arifin dkk. (2007) dalam Putranti dkk. (2015) bahwa kisaran suhu yang baik pada saat penebaran sampai akhir pemeliharaan yaitu $26-30{ }^{\circ} \mathrm{C}$.

Oksigen terlarut yang telah diukur selama penelitan menunjukkan hasil 4,4-6,6 mg/l. Nilai ini masih optimal untuk budidaya ikan mas. Menurut Zonneveld dkk. (1991) dalam Putranti dkk. (2015) ketersediaan oksigen terlarut dalam budidaya ikan mas tidak boleh kurang dari 3 $\mathrm{mg} / \mathrm{l}$.

Nilai $\mathrm{pH}$ yang diperoleh selama peneltian berkisar 7-7,9. Nilai ini masih optimal untuk kelangsungan hidup ikan mas. Menurut Effendi (2003) dalam Putranti dkk. (2015) sebagian besar biota akuatik menyukai pH 7-8,5

\section{Kesimpulan}

Berdasarkan hasil penelitian yang telah dilakukan bahwa penambahan getah pepaya dengan dosis berbeda pada pakan tidak memberikan pengaruh terhadap pertumbuhan berat mutlak, efisiensi pakan, kecernaan total, dan tingkat kelangsungan hidup ikan mas. Namun, penambahan getah pepaya $1 \%$ pada pakan memberikan pertumbuhan berat mutlak, efisiensi pakan dan kecernaan total cenderung lebih tinggi pada ikan mas.

\section{Ucapan Terima Kasih}

Ucapan terima kasih disampaikan kepada Zaenal Abidin yang telah membantu merancang penelitian dan Ni Kadek Puji Astuti yang telah banyak membantu selama penelitian.

\section{Daftar Pustaka}

Ananda, T., Diana, R., Istiyanto, S. (2015). Pengaruh Papain Pada Pakan Buatan Terhadap Pertumbuhan Ikan Patin (Pangasius hypopthalmus). Journal of Aquaculture Management and Technology. 4 (1), 47-53.

Anugraha, R, S., Subandiyono, Endang, A. (2014). Pengaruh Penggunaan Ekstrak Buah Nanas Terhadap Tingkat Pemanfaatan Protein Pakan dan Pertumbuhan Ikan Mas (Cyprinus carpio). Journal of Aquaculture Management and Technology, 3 (4), 238-246.

Arum, R, H., Budiatman, S., Harsi, D, K. (2014). Aktivitas Antibakteri Getah Pepaya Kering Terhadap Staphylococcus aureus Pada Dangke. Jurnal Teknologi dan Industri Pangan, 25 (1), 65-71.

DeMan, JM. (1997). Kimia Makanan. Bandung : Institut Teknologi Bandung.

Direktorat Jenderal Perikanan Budidaya Kementerian Kelautan dan Perikanan. (2014). Statistik DJPB. Retrieved from http://www.djpb.kkp.go.id/index.php/arsi p/c/209/DATA-STATISTIKLAINNYA/?category id=35.

Gusrina. 2008. Budi Daya Ikan Jilid 2. Jakarta: Direktorat Pembinaan Sekolah Menengah Kejuruan.

Handajani, H., \& Wahyu, W. (2010). Nutrisi Ikan. Malang: UMM Press. 
Haryanto, P., Pinandoyo., Restiana, W. A. (2014). Pengaruh Dosis Pemberian Pakan Buatan yang Berbeda Terhadap Pertumbuhan Juvenil Kerapu Macan (Epinephelus fuscoguttatus). Journal of Aquaculture Management and Technology, 3 (4), 58-66.

Hasan, O, D, S. (2000). Pengaruh Pemberian Enzim Papain dalam Pakan Buatan Terhadap Pemanfaatan Protein dan Pertumbuhan Benih Ikan Gurame (Osphronemus gourami Lac.). (Skripsi). Institut Pertanian Bogor.

Hutabarat, J., Dian, R., Istiyanto, S. (2016). Pengaruh Enzim Protease Papain dalam Pakan Buatan Terhadap Pertumbuhan dan Net Protein Ultilization Benih Ikan Lele yang Dibudidaya Di Desa Wonosari, Kecamatan Bonang, Kabupaten Demak. Pena Akuatika, 14 (1), 25-35.

Ismarani. (2012). Potensi Senyawa Tannin dalam Menunjang Produksi Ramah Lingkungan. Jurnal Agribisnis dan Pengembangan Wilayah, 3 (2).

Khodijah, D., Diana, R., Pinandoyo. (2015). Performa Pertumbuhan Benih Ikan Lele Sangkuriang (Clarias gariepinus) Melalui Penambahan Enzim Papain Dalam Pakan Buatan. Journal of Aquaculture Management and Technology, 4 (2), 3543.

Ningrum, R., Elly, P., Sukarsono. (2016). Identifikasi Senyawa Alkaloid dari Batang Karamunting (Rhodomyrtus tomentosa) Sebagai Bahan Ajar Biologi untuk SMA Kelas X. Jurnal Pendidikan Biologi Indonesia, 2 (3), 231-236.

Oliveira, J. G. D., Angela, P. V. (2011). Papaya: Nutritional and Pharmacological Characterization, and Quality Loss Due to Physiological Disorders. Food Research International. 44 (1), 1306-1313.

Putranti, G, P., Subandiyono., Pinandoyo. (2015). Pengaruh Protein dan Energi yang
Berbeda pada Pakan Buatan Terhadap Efisiensi Pemanfaatan Pakan dan Pertumbuhan Ikan Mas (Cyprinus carpio). Journal of Aquaculture Management and Technology. 4 (3), 38-45.

Rachman, A., Sri, W., Ike, Y. W. (2015). Isolasi dan Identifikasi Senyawa Saponin Ekstrak Metanol Daun Binahong (Anredera cordifolia (Ten.) Steenis). Program Studi Farmasi. Universitas Pakuan. Bogor.

Rachmawati, D., Johannes, H., Istiyanto, S. (2016). Aplikasi Enzim Papain dalam Pakan Buatan Sebagai Pemacu Pertumbuhan Upaya Percepatan Produksi Lele Sangkuriang di Kawasan Kampung Lele Desa Wonosari. Prosiding Seminar Nasional Kelautan. Universitas Trunojoyo. Madura.

Rohyami, Y. (2008). Penentuan Kandungan Flavonoid dari Ekstrak Metanol Daging Buah Mahkota Dewa (Phaleria macrocorpa Scheff Boerl). Jurnal Penelitian dan Pengabdian. 5 (1), 1-16.

Sani. (2008). Penambahan Natrium Bisulfit pada Kualitas Enzim Papain dari Getah Pepaya Secara MCU. Unesa University Press.

Suyanti., Setyadjit., Abdullah, B. A. (2012). Produk Diversifikasi Lahan Untuk Meningkatkan Nilai Tambah Dan Mendukung Pengembangan Buah Pepaya (Carica Papaya L) di Indonesia. Buletin Teknologi Pascapanen Pertanian, 8 (2), 62-70.

Usman., Asda, L., Erik, S. (2014). Suplementasi Crude Enzim Papain dalam Pakan Pembesaran Ikan Baronang (Siganus guttatus). Jurnal Perikanan, 16 (1), 11-16.

Yulianto, A. (2013). Cara Pas Pembesaran Ikan Mas. Semarang: Trans Idea Publishing. 